\title{
Behavioral Thermoregulation in Mice Inoculated With Influenza Virus
}

\author{
MARK S. KLEIN, CAROLE A. CONN AND MATTHEW J. KLUGER ${ }^{1}$ \\ Department of Physiology, The University of Michigan Medical School, Ann Arbor, MI 48109
}

Received 27 March 1992

\begin{abstract}
KLEIN, M. S., C. A. CONN AND M. J. KLUGER. Behavioral thermoregulation in mice inoculated with influenza virus. PHYSIOL BEHAV 52(6) $1133-1139,1992$.- Mice housed at $30^{\circ} \mathrm{C}$ and inoculated with a mouse-adapted influenza virus show a fall in body temperature $\left(T_{\mathrm{b}}\right)$ and a decrease in food intake to almost 0 grams per day. This study tested whether the fall in $T_{\mathrm{b}}$ could be accounted for by the decreased food intake and whether the fall in $T_{\mathrm{b}}$ was due to a decrease of thermoregulatory set point or to an inability to maintain $T_{\mathrm{b}}$ at set point level. The fall in $T_{\mathrm{b}}$ of influenza-infected mice was greater than that of food-deprived mice. When food deprived, mice given access to a thermal gradient increased their preference for warmer areas in the gradient and, as a result, $T_{\mathrm{b}}$ did not fall as much as $T_{\mathrm{b}}$ of starved mice not given access to a thermal gradient. When infected with influenza virus, mice given a thermal gradient decreased $T_{\mathrm{b}}$ less and at a slower rate than mice not given a gradient. However, this fall in $T_{\mathrm{b}}$ of influenza-infected mice was greater than that of food-deprived mice given a thermal gradient. Mice given a thermal gradient increased their preference for the warmer temperatures after inoculation; this returned to preinoculation preference for cooler temperatures during the later days of infection despite a continuous fall in $T_{\mathrm{b}}$. Influenza-infected mice given a thermal gradient survived significantly fewer days than infected mice not given a thermal gradient. We conclude that the influenza-induced fall of $T_{\mathrm{b}}$ in mice cannot be explained solely by the decrease in food intake, and is partially due to a decrease in thermoregulatory set point.
\end{abstract}

Thermal gradient Temperature Food deprivation Thermoregulatory set-point Behavioral thermoregulation

ALTHOUGH infection with influenza virus results in fever for humans and ferrets (8), inoculation of mice with a mouseadapted strain of influenza virus resulted in a fall in body temperature (11). In that study, mice housed individually at an ambient temperature of $30^{\circ} \mathrm{C}$ decreased food intake to nearly 0 grams per day, and significantly decreased water intake and activity. Since food deprivation has been found to result in a lowering of body temperature [e.g., $(6,7,18)]$, we wondered whether the reduction in food intake alone might account for the fall in body temperature $\left(T_{\mathrm{b}}\right)$ of the infected mice. We tested the hypothesis that mice subjected to starvation would show the same fall in temperature as infected mice that had voluntarily decreased food intake to almost zero.

It is not known whether the decrease in $T_{b}$ due to food deprivation is a regulated lowering of thermoregulatory set point, perhaps directed toward the goal of saving energy. If the fall in $T_{\mathrm{b}}$ is regulated, then mice given a thermal gradient, where they could select ambient temperatures as high as normal $T_{\mathrm{b}}$ (approximately $37^{\circ} \mathrm{C}$ ), should still show the starvation-induced decrease in $T_{\mathrm{b}}$. Alternatively, if the fall in $T_{\mathrm{b}}$ due to food deprivation is simply because the mice are unable to maintain their prestarvation $T_{\mathrm{b}}$ by physiological mechanisms, then they should select higher temperatures in the gradient to maintain $T_{\mathrm{b}}$ near its normal level throughout starvation. We gave mice access to a thermal gradient to test the hypothesis that they would be- haviorally maintain prestarvation $T_{\mathrm{b}}$ during the starvation period.

A previous study (12) has shown that lowered temperatures increased survival to bacteria or endotoxin challenge in young mice. The reduction in $T_{\mathrm{b}}$ in virus-infected mice may be a regulated response that has adaptive value (i.e., improves survival). Alternatively, the thermoregulatory set point may be unchanged. Lowering of $T_{\mathrm{b}}$ might then be due to an inability to maintain normal temperatures, or to develop fever, by physiological means. We permitted influenza-infected mice access to a thermal gradient to test the hypothesis that they would maintain preinoculation temperatures or develop fever by behaviorally selecting a warmer environment.

\section{METHOD}

Animals

Male Swiss Webster mice [Tac:(SW)fBR], aged 24 to 35 days, caesarean-derived gnotobiotic and barrier maintained, were obtained from Taconic Laboratories (Germantown, NY). The mice were housed either one to a cage (covered with filter paper to prevent virus particles from leaving the cage) or in terraria (see below). The room where all mice were housed was a temperaturecontrolled chamber set at $30 \pm 1{ }^{\circ} \mathrm{C}$, a temperature within the thermoneutral zone for mice. For protocols 2 and 3 (see below),

${ }^{1}$ Requests for reprints should be addressed to M. J. Kluger. 
this temperature was lowered to $25 \pm 1{ }^{\circ} \mathrm{C}$. The rooms were on a 12:12 (h) light:dark cycle, with light onset at $0600 \mathrm{~h}$.

\section{Body Temperature Measurement}

Deep body temperature $\left( \pm 0.1^{\circ} \mathrm{C}\right)$ was measured using implanted telemetry transmitters (Mini-Mitter, Sunriver, OR). At least 1 week prior to experimentation, mice were anesthetized with methoxyflurane (Metofane, Pitman-Moore, Mundelein, IL). For each mouse, the lower abdomen was shaved and washed with alcohol. An incision (approximately $2 \mathrm{~cm}$ ) was then made in the abdomen into which the transmitter was placed. The abdomen was sutured closed with 3-0 silk, the wound area swabbed with nitrofurazone (Furacin, Norwich Eaton, Norwich, NY), and the mouse returned to his cage. Each transmitter was calibrated before implantation and after experimentation to verify that the collected temperature values were valid. The output of each transmitter was received by an antenna under each animal's cage (see below for terraria) and fed into a peripheral processor connected to an IBM PC. This Dataquest III system (Mini-Mitter, Sunriver, OR) allowed us to continuously monitor and record $T_{\mathrm{h}}$ at 5-min intervals without handling the animals. See (16) for a more detailed description of this temperature-measurement protocol

\section{Terraria}

With the exception of protocol 1, all experimentation was done with the mice housed in large modified cages. The cages were plastic fish aquaria divided in half lengthwise with a sheet of aluminum, such that each side housed one mouse in a compartment $122 \mathrm{~cm}$ long $\times 38 \mathrm{~cm}$ high $\times 20 \mathrm{~cm}$ wide. The aluminum divider was continued underneath the terrarium, which sat on wood supports $4 \mathrm{~cm}$ off the ground. This divider prevented transmitter signals originating in a mouse on one side of the terrarium from being picked up by antennae under the other side of the terrarium. Three Mini-Mitter antennae $(33 \times 23 \times$ $1.5 \mathrm{~cm}$ ) were placed at equal intervals on each side of the terrarium. This allowed transmitter signals to be received from each mouse no matter where he was in the terrarium at any given time. Plexiglas dividers (placed at $40.7 \mathrm{~cm}$ intervals) further sectioned each side of the terrarium into thirds, with a $5.3 \mathrm{~cm}$ window at the bottom of each divider, allowing the mouse to roam freely from one section to another under the dividers. All cages were covered with filter paper, which served in protocol 3 (see below) to prevent virus particles from leaving the terrarium. Bedding (Sani-chip, P. J. Murphy Forest Products, Inc., Montville, NJ) in the terrarium was originally no more than $1 \mathrm{~cm}$ thick (mice often burrowed in bedding, making some areas thicker than others).

\section{Food and Water}

Food was provided ad lib in all experiments except for starvation periods (see protocols 1 and 2 ). In the experiments with mice housed in terraria (protocols 2 and 3), two pellets of rodent chow (Purina 5001, Purina Mills, Inc., St. Louis, MO) were placed in each of the three sections for each mouse. Each day, $4 \mathrm{~h}$ after the onset of light, food from the previous day was removed, weighed, and replaced; mice were also weighed at this time. Tap water was provided ad lib throughout all experiments. In the terrarium, one water bottle per section was hung upsidedown, tied by copper wire to a bar across the top of each terrarium.

\section{Thermal Gradient}

A $250 \mathrm{~W}$ heat lamp was placed $11 \mathrm{~cm}$ above one end of each terrarium for protocols 2 and 3 (see below). Due to the thin covering of filter paper above the terrarium, the Plexiglas dividers. and perhaps the absorption properties of the bedding, a thermal gradient was easily attainable. Temperature in the terrarium was measured before protocol 2 by placing Mini-Mitter transmitters at 12 locations in each terrarium on top of the same amount of bedding used in the experiments. Temperature was recorded once every $5 \mathrm{~min}$ for a total of $60 \mathrm{~min}$ ( 12 recordings), and this was repeated for the nighttime, when the lights in the temperature controlled chamber were off. Ambient temperature in the chamber was monitored continuously using thermocouples connected to a Digistrip recorder, which recorded temperature every hour throughout experimentation.

Temperatures in the hot sections of the terraria averaged $36.38^{\circ} \mathrm{C} \pm 0.63 \mathrm{SEM}$, temperatures in the warm sections of the terraria averaged $27.73^{\circ} \mathrm{C} \pm 0.27 \mathrm{SEM}$, and temperatures in the $\mathrm{cool}$ sections of the terraria averaged $25.32^{\circ} \mathrm{C} \pm 0.17 \mathrm{SEM}$.

\section{Influenza Virus}

Viral infections were induced in mice lightly anesthetized with methoxyflurane (Metofane, Pitman-Moore, Mundelein, IL) by intranasal inoculations of $50 \mu \mathrm{l}$ of allantoic fluid containing a mouse-adapted influenza virus (H1N1-A/PR/8/34) grown in 10-day-old embryonated SPAFAS eggs. The inoculum was diluted with a Hanks balanced salt solution into selected doses expressed as plaque-forming units (PFU) that were defined in Madin-Darby canine kidney cells (MDCK cells, NBL-2, ATCC CCL34). Inoculations were performed at 1000-1030 h.

The virus is believed to be transmittable through the air in the presence of moisture. Two precautions were taken to prevent mice from inadvertently coming in contact with virus particles from other infected mice (which could thereby affect their own virus dosage). First, terraria in the virus experiments (as well as all other experiments) were covered with a special filter paper. Second, to prevent inadvertent infection of subsequent animals housed in terraria previously used for infected mice, terraria were allowed to air dry for at least 2 days after bedding was manually removed.

\section{Experimental Design}

Protocol 1: Does 48-h starvation of mice result in a similar lowering of body temperature as inoculation of mice with influenza virus? Twelve mice were housed singly at $30 \pm 1^{\circ} \mathrm{C}$ ambient temperature in standard cages $(32.5 \times 21 \times 19 \mathrm{~cm})$. Six were then food deprived for $48 \mathrm{~h}$ to simulate the food intake measured during infection of mice with a high dose of virus (55,000 PFU). Water was provided ad lib. No differences in weight were present between the two groups prior to the onset of this experiment. Temperature data were collected from 1 day prior to the starvation period to 4 days after the 48 -h starvation period. Food intake, water intake, and body weight were recorded daily. Temperatures were compared between the starved and fed conditions to see if starvation led to a change in $T_{\mathrm{b}}$. Data from the starved mice were then compared with data from influenza-infected mice in which seven mice were housed singly in the same types of cages and at the same ambient temperature $\left[30^{\circ} \mathrm{C}(11)\right]$.

Protocol 2: Given a thermal gradient, will mice starved for $48 \mathrm{~h}$ show a lowering of body temperature? Sixteen mice were used for this experiment with eight mice being housed in terraria with a thermal gradient and eight mice being housed in terraria without a thermal gradient. Ambient temperature of the room 
was set to $25 \pm 1^{\circ} \mathrm{C}$, because a previous gradient experiment suggested that $30^{\circ} \mathrm{C}$ might not be low enough if mice wanted to move to a cooler ambient temperature. Ambient temperature of mice in the thermal gradient varied as described above. Food intake was recorded daily, and body weight was measured every day except for the 1 day in the middle of the 48 -h starvation period. Temperature data were collected every $5 \mathrm{~min}$ from 2 days before the 48-h starvation period through the third day after the 48-h starvation period. The mice were in terraria for $25 \mathrm{~h}$ before any data were collected. According to preexperimental analyses of circadian rhythm following cage switch (mice were housed in normal cages before being moved to terraria), this was sufficient time to allow their temperature rhythms to return to normal after being placed in the new environment.

One mouse belonging to the nongradient group was deleted from the data analysis due to a dripping water bottle, which seemed to empty gradually during the night of the first day of the poststarvation period, forcing the mouse to a different section of the terrarium and perhaps inducing a stress response. Another mouse belonging to the nongradient group was deleted from the data analysis because it died on the second day of the poststarvation period. $T_{\mathrm{b}}$ of this mouse, preceding his death, was very low.

Protocol 3: Given a thermal gradient, will influenza-infected mice show a lowering of body temperature? Sixteen mice were used for this experiment, with eight mice originally housed in terraria with a thermal gradient and eight mice originally housed in terraria without a thermal gradient. As in protocol 2 , ambient temperature of the room was $25 \pm 1^{\circ} \mathrm{C}$, and this was taken to be the ambient temperature of the nongradient terraria. Ambient temperature of mice in the thermal gradient varied as described above. Mice were inoculated with influenza virus (see above), and temperature data were collected from 2 days before the first day of infection (inoculation day) through the ninth day of infection. Food intake was recorded daily.

Only mice that were sick as a result of the inoculation with virus (i.e., temperature and food intake decreased) were included for analysis in this study. The sample sizes of six mice housed in the gradient and three mice housed in the nongradient conditions do not include one nongradient mouse that appeared to be sick before inoculation with virus (based on a decreased food intake and low temperature), two nongradient mice that died at the time of inoculation, and two mice each from gradient and nongradient groups which did not appear to get sick (based on food intake and temperature).

\section{Data Analysis}

Temperature measurements were averaged over 24-h periods for each mouse. In protocol 1 , temperature comparisons over time were made by first performing a one-way repeated measures ANOVA to determine whether or not a significant $(p<0.05)$ interaction was present between time and group factors. Student's $t$-test was then used to compare baseline and temperatures during food deprivation of starved mice with those of fed controls. Both Student's $t$-test and analysis of covariance, using weight and baseline temperature as the covariates, were used to compare temperatures during treatment of starved mice from protocol 1 with those of influenza-infected mice from another study (11). In addition, the drop in temperature from baseline $T_{\mathrm{b}}$ to $T_{\mathrm{b}}$ during starvation was compared between starved and influenzainfected mice using Student's $t$-test. For protocols 2 and 3, Student's $t$-test was used following the ANOVA to make intergroup comparisons (gradient versus nongradient mice) to determine on what days temperature differences were present. A paired $t$ - test was done to make intragroup comparisons between temperatures before starvation (or inoculation) and temperatures after starvation (or inoculation).

Food intake, water intake, and weight comparisons between groups were done using Student's $t$-test.

Survival data for protocol 3 were obtained by counting the number of whole days (fractions were truncated) a mouse survived after inoculation. Student's $t$-test was then done between gradient and nongradient groups.

An analysis of behavioral thermoregulation was done to see if preferred ambient temperature changed (for mice given thermal gradients in protocols 2 and 3) during the course of the experiments. For the starvation experiments in protocol 2 , temperature recordings from each section of the terraria were totalled for the day immediately prior to starvation (hours -24 to 0 ), the second day of starvation (hours 25 to 48 ), and the third day of the poststarvation period (hours 97 to 120). For the influenza experiments in protocol 3 , temperature recordings were totalled for the first-day preinoculation and the fourth day of infection. These totals were then converted to a proportion of time spent in each section. To normalize the data, the inverse sine of the square root of the proportion $\left(\sin ^{-1}(\sqrt{x})\right.$ was calculated. A single factor (section of terrarium) repeated measures ANOVA was then performed on the transformation (significance level was taken to be $\alpha=0.05$ ), followed by a post hoc Scheffe $F$-test for pairwise comparisons between time periods. This procedure was repeated with the nongradient mice as a control, to make sure that other variables besides temperature were not affecting location preference in terraria.

As an estimate of the preferred ambient temperature of mice in the thermal gradient, we added the proportion of time spent on each board multiplied by the average temperature on the respective board to yield a weighted average-preferred ambient temperature.

\section{RESULTS}

Protocol 1: Does 48-h Starvation of Mice Result in a Similar Lowering of Body Temperature as Inoculation of Mice With Influenza Virus?

Effect of starvation on body temperature $\left(\mathrm{T}_{b}\right)$ of mice. Mice starved for $48 \mathrm{~h}$ at an ambient temperature of $30^{\circ} \mathrm{C}$ showed a significant decrease (Student's $t=13.148, p<0.0001$ ) in temperature as compared to fed controls (Fig. 1). $T_{\mathrm{b}}$ of starved mice decreased $0.81^{\circ} \mathrm{C}$ from $37.56^{\circ} \mathrm{C}$ (day -1) before the starvation period to $36.75^{\circ} \mathrm{C}$ (day 2) on the second day of starvation. The temperature of control mice did not change significantly $\left(37.65^{\circ} \mathrm{C}\right.$ on 1 day prior starvation, and $37.66^{\circ} \mathrm{C}$ on the second day of starvation). Water intake for the starved group dropped from $12.0 \mathrm{~g}$ before the starvation period to $8.6 \mathrm{~g}$ on the second day of starvation, and this was significantly lower than controls ( $p<0.013$ by Student's $t$-test). The starved mice lost $15.2 \%$ of their original weight over the 48-h starvation period (from 30.2 $\mathrm{g}$ to $25.6 \mathrm{~g}$ ). The fed controls increased their weight by $4.4 \%$ over the 48-h starvation period, and the weight difference between the fed control and starved mice was significant at the end of the starvation period ( $p<0.0015$ by Student's $t$-test).

Comparison between $\mathrm{T}_{b}$ of starved and influenza-infected mice. Figure 2 shows a comparison between temperatures of influenza-infected mice on the third day of infection [maintained at an ambient temperature of $30^{\circ} \mathrm{C}$; data from (11)], which had been preceded by $24 \mathrm{~h}$ of nearly zero food intake $(0.4 \mathrm{~g}$ per day, for infection days 2 and 3, compared to an average of $4.2 \mathrm{~g}$ per day for each mouse during the preinoculation period), and that of starved mice (also maintained at $30^{\circ} \mathrm{C}$ ) on the second day of 


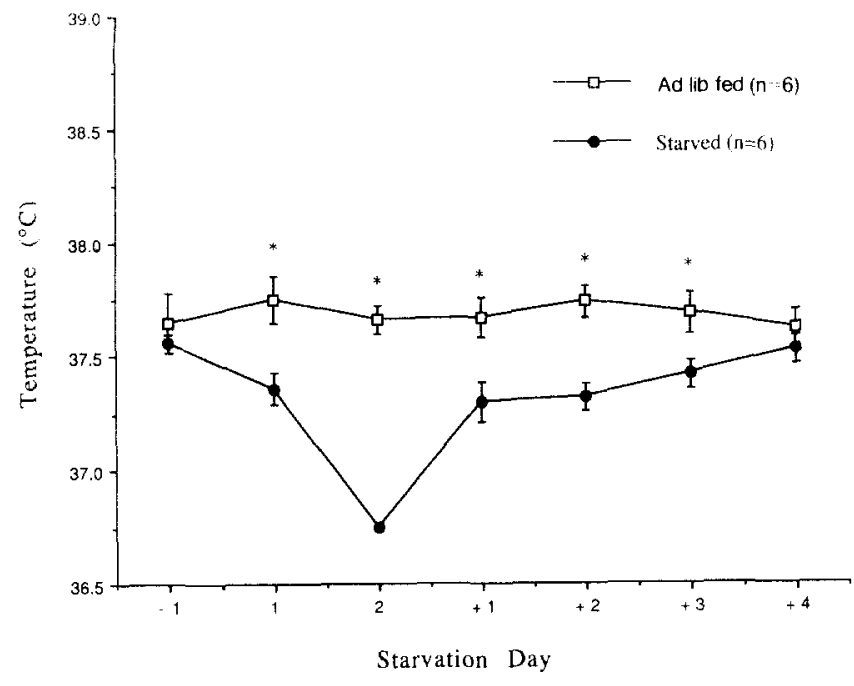

FIG. 1. Twenty-four-hour average $T_{\mathrm{b}}$ of mice housed at $30^{\circ} \mathrm{C}$ ambient temperature for 1 day prior to starvation $(-1), 2$ days of starvation (1 and 2), and 4 days after the starvation period ( +1 to +4$)$, compared to ad lib-fed controls. Temperature values are plotted as mean $\pm 1 \mathrm{SE}$, and significance values were determined by Student's $t$-test. ${ }^{*}$ Denotes $p<$ 0.008 .

starvation. Baseline temperatures for both groups are also shown. The 24-h average temperature for the third day of infection was compared with the temperatures for the second day of starvation to see if a similar fall in temperature occurred. Despite eating more food and having a lower core temperature prior to infection, the influenza-infected mice showed a significantly greater fall in temperature after $48 \mathrm{~h}$ (infection day 3 ) of nearly zero food intake $\left(-1.63^{\circ} \mathrm{C}\right.$ versus $-0.81^{\circ} \mathrm{C}$ for the starved mice, $p<$ 0.0015 ).

In addition to having lower core temperatures before treatment, the influenza-infected mice weighed significantly more than the starved mice ( $34.5 \mathrm{~g}$ and $29.1 \mathrm{~g}$, respectively, $p<0.02$ ). To be sure that the difference between groups in $T_{\mathrm{b}}$ during starvation was not influenced by weight or by baseline $T_{\mathrm{b}}$, we used these variables as covariates in an analysis of covariance. The results of this analysis also showed that the infected mice had significantly lower $T_{\mathrm{b}}$ than the starved mice following 2 days of little or no food intake.

Protocol 2: Given a Thermal Gradient, Will Mice Starved for 48 h Show a Lowering of Body Temperature?

Figure 3 shows the mean $T_{\mathrm{b}}$ for the gradient (ambient temperature approx. $25-36^{\circ} \mathrm{C}$ ) and nongradient (ambient temperature approximately $25^{\circ} \mathrm{C}$ ) groups during the prestarvation period through the third day of the poststarvation period. No significant difference in pretreatment weight was present between the gradient $(33.9 \mathrm{~g})$ and nongradient $(33.0 \mathrm{~g})$ groups $(p>0.6)$. On the second day of starvation, the mice given a gradient had a significantly higher $T_{\mathrm{b}}$ than the nongradient mice $\left(36.5^{\circ} \mathrm{C}\right.$ and $34.7^{\circ} \mathrm{C}$, respectively; Student's $t=2.37, p<0.02$ ). Intragroup comparisons between prestarvation and starvation-period temperatures showed that both the gradient group and nongradient groups significantly decreased $T_{\mathrm{b}}$ as compared with prestarvation temperature. $T_{\mathrm{b}}$ of the gradient mice fell a maximum of $0.83^{\circ} \mathrm{C}$ on the second day of starvation, and $T_{\mathrm{b}}$ of the nongradient mice fell a maximum of $2.72^{\circ} \mathrm{C}$ on the second day of starvation. Both groups increased $T_{\mathrm{b}}$ over the next 3 days, but never recovered

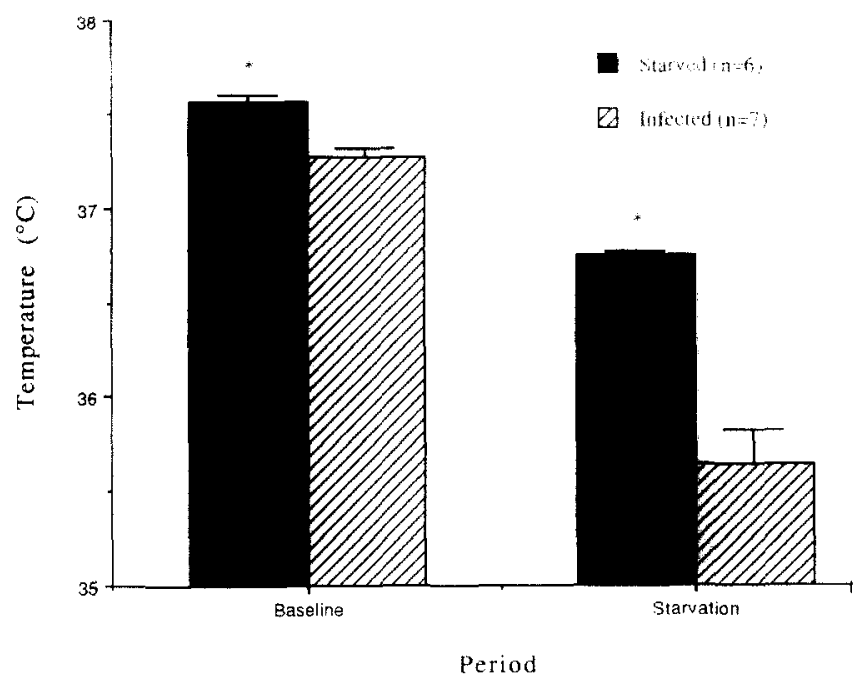

FIG. 2. Baseline temperature comparisons between mice infected with influenza virus and starved mice prior to treatment, and temperature comparisons between starved mice on the last day of the 48-h starvation period and influenza-infected mice after an equivalent time period with $0.4 \mathrm{~g}$ food intake per day. Mice were housed at $30^{\circ} \mathrm{C}$ ambient temperature. Values are plotted as mean $\pm 1 \mathrm{SE}$, and significance values were determined by Student's $t$-test. *Denotes $p<0.002$.

completely to the prestarvation average temperature (temperatures on the third-day poststarvation were $0.1^{\circ} \mathrm{C}$ and $0.3{ }^{\circ} \mathrm{C}$ cooler for the gradient and nongradient mice, respectively).

For mice given a thermal gradient, Fig. 4 shows the proportion of time spent in each section prior to, during, and following starvation. Mice spent a significantly greater proportion of time in the hot ends of their terraria during the starvation period than before or after starvation $(F>50, p<0.0001$; post hoc Scheffe

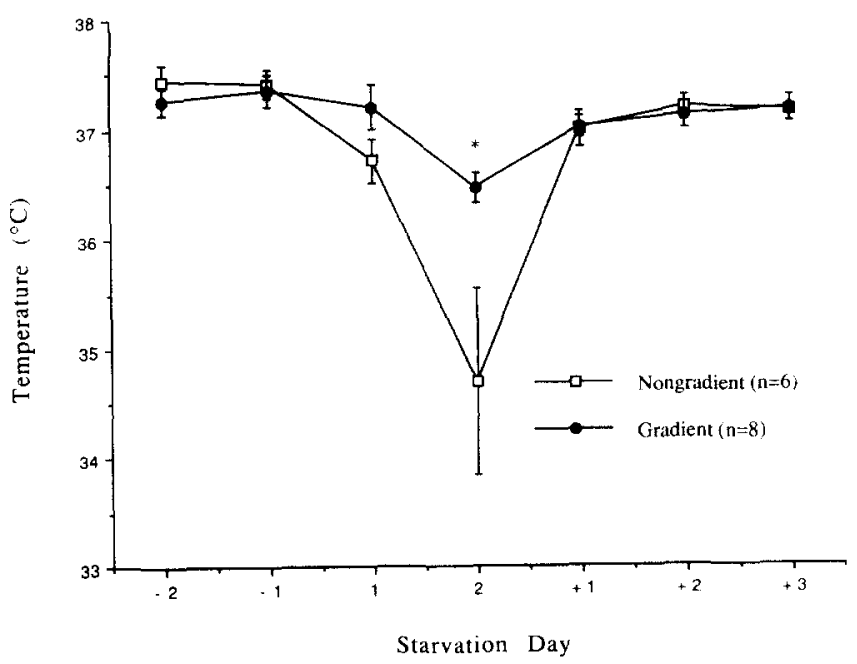

FIG. 3. Twenty-four-hour average $T_{\mathrm{b}}$ for starved mice housed without a thermal gradient (ambient temperature approximately $25^{\circ} \mathrm{C}$ ) compared to starved mice in a thermal gradient (ambient temperature approximately, $25-36^{\circ} \mathrm{C}$ ) for 2 days prior to starvation $(-2$ and -1$), 2$ days of starvation ( 1 and 2$)$, and 3 days after the starvation period $(+1$ to +3$)$. Temperature values are plotted as mean \pm 1 SE. Significance values were determined by Student's $t$-test. *Denotes $p<0.05$. 


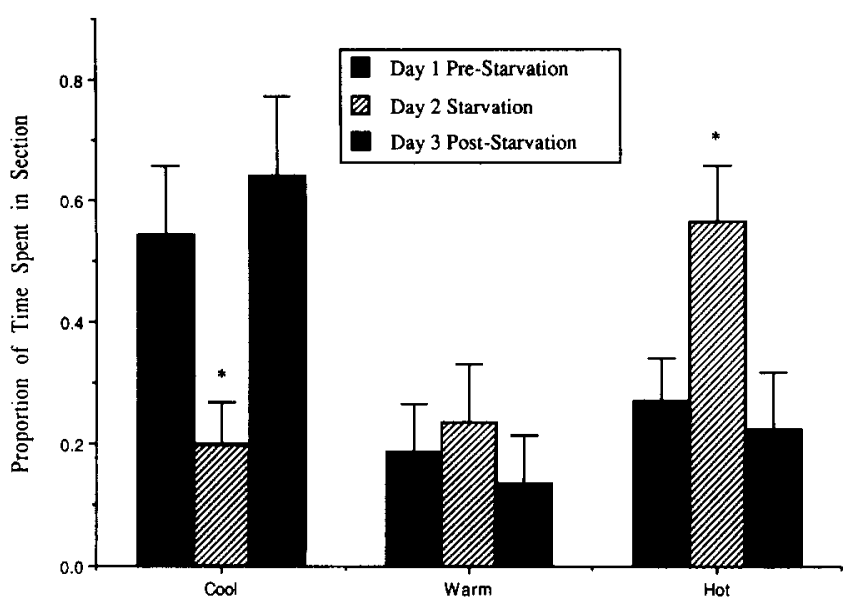

FIG. 4. Preferences of gradient sections for mice given a thermal gradient on the day prior to starvation, the second day of starvation (hours 25 to 48 ), and on the third day after food was restored (hours 49 to 72 poststarvation). Values are plotted as mean proportion of time spent in each section \pm 1 SE. Significance values were determined by Scheffe $F$-test. *Denotes $p<0.05$ as compared to pre- and poststarvation proportions.

$F>30, p<0.01$ for comparisons with pre- and poststarvation days). No change in preference was seen in any sections for the nongradient mice. Average preferred floor temperature was greatest on day 2 of starvation (Fig. 7).

\section{Protocol 3: Given a Thermal Gradient, Will Influenza-Infected Mice Show a Lowering of Body Temperature?}

Figure 5 shows the temperatures of the gradient (ambient temperature approximately $25-36^{\circ} \mathrm{C}$ ) and nongradient (ambient temperature approximately $25^{\circ} \mathrm{C}$ ) groups from the preinoculation period through the ninth day of influenza infection. No significant baseline differences were present between groups ( $p$ $>0.45$ ). However, the significant interaction of group $\times$ time, $F(1,7)=11.066, p<0.0001$, on temperature from preinoculation through the seventh day of infection suggests that the decrease in temperature of the nongradient mice was faster and greater in magnitude. Temperatures of mice for the third day of infection had dropped $3.42^{\circ} \mathrm{C}$ for the nongradient mice and $1.85^{\circ} \mathrm{C}$ for the gradient mice $(p<0.04)$. On the sixth day of infection, temperatures for the nongradient mice had fallen $7.05^{\circ} \mathrm{C}$, while temperatures for the gradient group had fallen $3.33^{\circ} \mathrm{C}(p<0.001)$.

Figure 6 shows the proportion of time spent in each section of the gradient for mice given a thermal gradient prior to and during infection day 4 . The mice spent a significantly greater proportion of time in the hot ends of their terraria on infection day 4 , when food intake was near its lowest value for the infection period, as opposed to before inoculation (paired $t=8.12, p<$ 0.0006 ). Mice spent a significantly greater proportion of time in the cool ends of their terraria before inoculation compared to the fourth day of infection (paired $t=8.41, p<0.0005$ ). No change in preference was seen in any sections for the nongradient mice.

Figure 7 shows the average preferred floor temperature for the gradient mice in starved and infected conditions. Both $T_{\mathrm{b}}$ from day 2 until death-and preferred floor temperature-from day 5 until death-decreased in mice infected with influenza. Infected mice began to decrease their food intake by the second

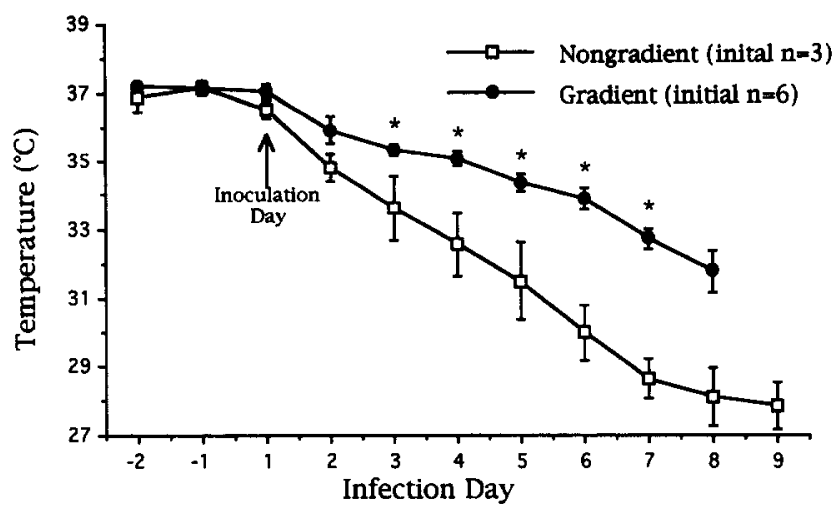

FIG. 5. Twenty-four-hour average $T_{\mathrm{b}}$ for influenza-infected mice housed without a thermal gradient (ambient temperature approximately $25^{\circ} \mathrm{C}$ ) compared to infected mice in a thermal gradient (ambient temperature approximately $25-36^{\circ} \mathrm{C}$ ) for 2 days prior to inoculation and 9 days of infection. Temperature values are plotted as mean $\pm 1 \mathrm{SE}$. Significance values were determined by Student's $t$-test. All gradient mice were dead after infection day 8 . ${ }^{*}$ Denotes $p<0.05$.

day of infection. Food intake was decreased by $81.7 \%$ on the third day of infection to $0.63 \mathrm{~g}$ for mice maintained in the gradient. The data graphed in Fig. 7 clearly show that $T_{\mathrm{b}}$ of influenza-infected mice on the third day of infection, despite the intake of small amounts of food, is much lower than that of starved mice on day 1 or 2 of starvation. On infection day $3, T_{\mathrm{b}}$ of infected mice had fallen $1.85^{\circ} \mathrm{C}$ from preinoculation temperatures as compared with a fall of $0.84^{\circ} \mathrm{C}$ in $T_{\mathrm{b}}$ of starved mice on day 2 of starvation $(p<0.0003)$. Furthermore, although body temperature of the infected mice continued to fall, they did not attempt to raise their temperatures by selecting a warmer floor temperature.

Although the sample sizes were small, nongradient mice survived significantly longer after inoculated with virus than the mice given a thermal gradient (8.33 days as compared to 6.17 days, $p<0.025$ ). Survivorship data are shown in Table 1 .

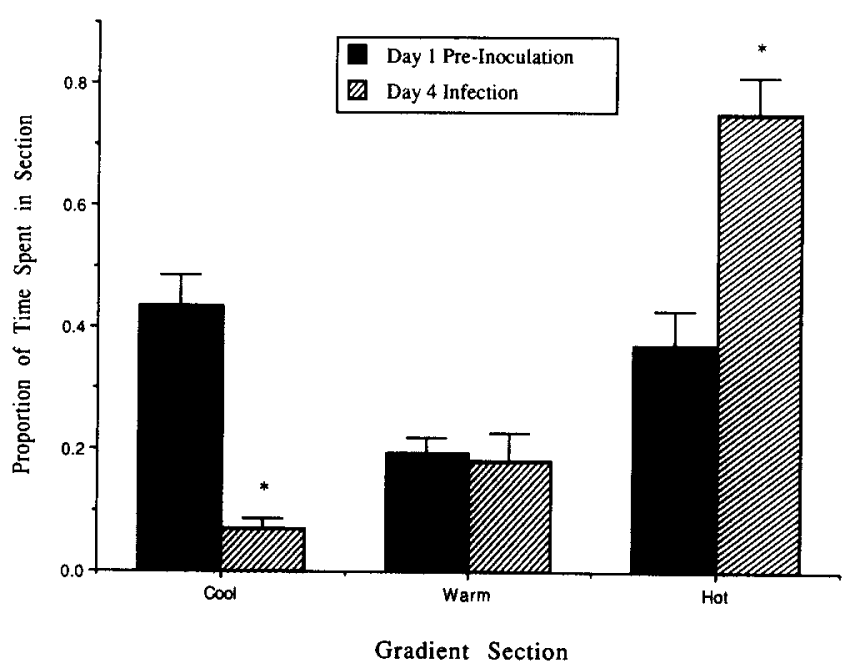

FIG. 6. Preferences of gradient sections for mice given a thermal gradient on the day prior to inoculation and the fourth day of influenza infection. Values are plotted as mean proportion of time spent in each section \pm $1 \mathrm{SE}$. Significance values were determined by paired $t$-test. ${ }^{*}$ Denotes $p$ $<0.0006$ as compared to preinoculation proportions. 


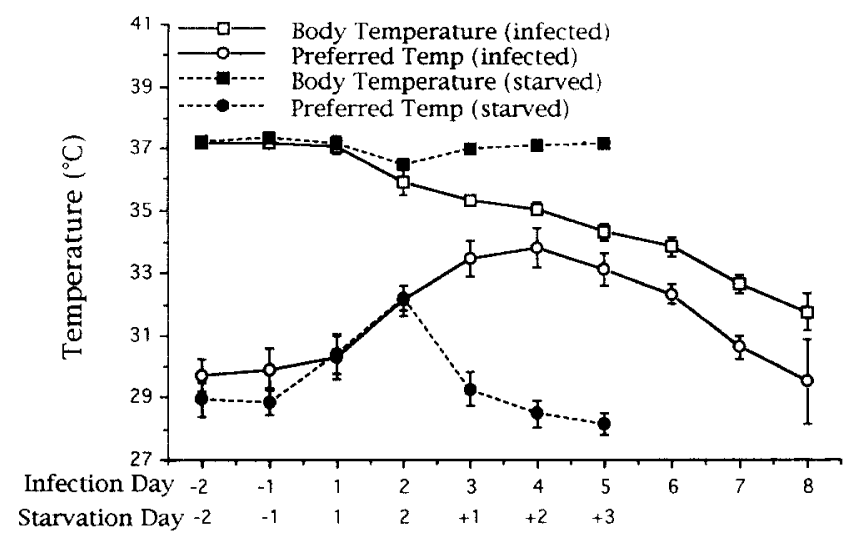

FIG. 7. Twenty-four-hour $T_{\mathrm{b}}$ and preferred floor temperatures averages for starved $(n=8)$ and influenza-infected mice (initial $n=6$ ) with access to the thermal gradient. The starvations days are: 2 days prior to starvation $(-2$ and -1$), 2$ days of starvation ( 1 and 2$)$, and 3 days after the starvation period $(+1$ to +3$)$. The infection days are: 2 days prior to infection $(-2$ and -1$)$ and 8 days of infection with influenza virus. All values are plotted as mean $\pm 1 \mathrm{SE}$.

\section{DISCUSSION}

The primary goal of this study was to determine the mechanism behind the influenza-induced fall in $T_{\mathrm{b}}$ of mice. Since infected mice decrease their food intake, we compared the $T_{\mathrm{b}}$ of mice fed ad lib with that of food-deprived mice. We found that $48 \mathrm{~h}$ of starvation significantly lowered $T_{\mathrm{b}}$ of healthy mice, and this is consistent with results of other studies showing that food deprivation can lead to a decrease in $T_{\mathrm{b}}$ [e.g., $\left.(6,7,18)\right]$. However, the fall in $T_{\mathrm{b}}$ of mice which were food-deprived for $48 \mathrm{~h}$ was less than the fall in $T_{\mathrm{b}}$ of infected mice after 2 days of very low food intake. We conclude that, although the decrease in $T_{\mathrm{b}}$ of the influenza-infected mice may be partially due to decreased food intake, even complete starvation cannot account for the entire fall in $T_{\mathrm{b}}$ following infection.

Additional support for this conclusion comes from experiments with mice given a thermal gradient. Figure 7 shows that mice preferred almost identical floor temperatures (within $0.1^{\circ} \mathrm{C}$ ) on the second day of both treatments. However, the influenzainfected mice showed a $0.55^{\circ} \mathrm{C}$ greater decrease in $T_{\mathrm{b}}$ on this day. Clearly, other effector mechanisms were activated in the infected condition that did not operate during starvation.

The additional experiments were run to compare the effects of starvation or infection on $T_{\mathrm{b}}$ and temperature selection of mice given a gradient. In one experiment, mice were starved for 2 days and given access to a thermal gradient (gradient temperature approximately $25-36^{\circ} \mathrm{C}$ ) or no gradient (ambient temperature approximately $25^{\circ} \mathrm{C}$ ). In the thermal gradient, mice showed a maximum fall in $T_{\mathrm{b}}$ of only $0.83^{\circ} \mathrm{C}$ to $36.47^{\circ} \mathrm{C}$. Without the thermal gradient, $T_{\mathrm{b}}$ fell a maximum of $2.72^{\circ} \mathrm{C}$ to $34.70^{\circ} \mathrm{C}$ (Fig. 3). The small fall in temperature of starved mice in the thermal gradient is consistent with the hypothesis that at most, a small decrease in thermoregulatory set point had occurred in the starved mice. However, this $0.84^{\circ} \mathrm{C}$ decrease in $T_{\mathrm{b}}$ might simply be the error signal necessary to initiate thermoregulatory effector responses.

In protocol 3, mice were inoculated with virus and given access to a thermal gradient (gradient temperature approximately $25-36^{\circ} \mathrm{C}$ ) or no gradient (ambient temperature approximately $25^{\circ} \mathrm{C}$ ). Results indicate that $T_{\mathrm{b}}$ of the gradient mice did not fall nearly as much as $T_{\mathrm{b}}$ of the nongradient mice (Fig. 5). This suggests 10 us that a portion of the fall in $\%_{\mathrm{h}}$ of influenea-infected mice may be due to an exhaustion of BAT reserves, or to a decrease in heat production occurring through an unknown mechanism. However infected mice did not maintain preinoculation temperatures by behavioral selection. As the infection progressed, these mice actually selected a cooler floor temperature. This supports the hypothesis that much of the fall in $T_{\mathrm{b}}$ of influenza-infected mice is regulated (i.e., their thermoregulatory set point has decreased).

Unlike data from studies of larger endotherms or ectotherms in which fever appears to be beneficial $[$ e.g., $(9,10)]$, our data support the hypothesis that the lowering of $T_{\mathrm{b}}$ during influenza infection in mice increases survival rate (Table 1). Furthermore, Conn et al. (unpublished data from our laboratory) inoculated 25 mice with influenza virus and housed them in standard cages, 13 mice at an ambient temperature of $30^{\circ} \mathrm{C}$, and 12 mice at $22^{\circ} \mathrm{C}$. In this study, $T_{\mathrm{b}}$ was not measured, but mice in the cool environment survived significantly longer than the mice at $30^{\circ} \mathrm{C}$ $(t=2.099, p<0.05)$. These results are similar to the data shown in Table 1, and support the hypothesis that a cooler ambient temperature, and perhaps lower $T_{\mathrm{b}}$, is beneficial for survival of these mice.

Similar to our results, other studies have shown that mice decrease thermoregulatory set point (seek cooler temperatures in a gradient) and/or show increased survivorship at lower ambient temperatures when injected with toxic substances [e.g., $(1,4,5,17)]$. An experiment by Lagerspetz and Väätäinen (12) showed that lowered temperature can increase survival rate of mice. In that study, young mice were infected with bacteria or with endotoxin. These 3-10-day-old mice actively sought cooler temperatures in a thermal gradient and showed a fall in $T_{\mathrm{b}}$, which resulted in increased resistance and tolerance to the infection. We speculate that a lowered thermoregulatory set point may be an adaptive response to infection or other stresses in small endotherms.

In summary, this study provides evidence that the decrease in body temperature of influenza-infected mice is, in part, a regulated fall. The decline is probably not due to a decrease in food intake alone, since mice starved for $48 \mathrm{~h}$ showed a significantly smaller fall in $T_{\mathrm{b}}$. What is responsible for the fall in $T_{\mathrm{b}}$ is not known. The fall in $T_{\mathrm{b}}$ not attributable to the reduced thermoregulatory set point may be due to a decreased metabolic

TABLE 1

SURVIVORSHIP

\begin{tabular}{lcc}
\hline & $\begin{array}{c}\text { Gradient Mice } \\
\text { Surviving }\end{array}$ & $\begin{array}{c}\text { Nongradient Mice } \\
\text { Surviving }\end{array}$ \\
\hline Preinoculation & 6 & 3 \\
Day & 6 & 3 \\
1 & & \\
2 & 6 & 3 \\
3 & 6 & 3 \\
4 & 6 & 3 \\
5 & 6 & 3 \\
6 & 6 & 3 \\
7 & 5 & 3 \\
8 & 3 & 2 \\
9 & 0 & 2 \\
\hline
\end{tabular}

Number of gradient and nongradient mice alive on each infection day. A mouse dying on a given day was not counted to have survived that day. 
rate. That portion of the fall in $T_{\mathrm{b}}$ due to the reduced set point may be the result of endogenous antipyretics or cryogens such as TNF [see $(2,13)], \alpha$-melanocyte-stimulating hormone [see $(3,14)]$, arginine vasopressin $(15)$, or others.

\section{ACKNOWLEDGEMENTS}

We thank Dr. M. Anthony Schork for his statistical assistance regarding the normalization of behavioral thermoregulation data and help with the ANCOVA; we also thank Mr. C. W. Smitka and Dr. H. F. Maassab for their development of the virus strain used in this research and their help with preparing the virus for inoculation. M.S.K. thanks Dr. Brenda K. Smith for her numerous suggestions regarding alternative ways of interpreting and analyzing data, as well as several insights into relative philosophy; M.S.K. also thanks Ms. Michele Clabaugh for her support over the Internet that, in the early research stages, made long nights of tedious gradient testing possible. Research supported by ONR N00014-90-J-1547 to M.J.K.

\section{REFERENCES}

1. Baetjer, A. M.; Smith, R. Effect of environmental temperature on reaction of mice to parathion, an anticholinesterase agent. Am. J. Physiol. 186:39-46; 1956.

2. Bauss, F.; Dröge, W.; Männel, D. N. Tumor necrosis factor mediates endotoxic effects in mice. Infect. Immun. 55:1622-1625; 1987.

3. Glyn, J. R.; Lipton, J. M. Hypothermic and antipyretic effects of centrally administered ACTH (1-24) and alpha melanotropin. Peptides 2:177-203; 1981

4. Gordon, C. J.; Mohler, F. S.; Watkinson, W. P.; Rezvani, A. H. Temperature regulation in laboratory mammals following acute toxic insult. Toxicology 53:161-178; 1988.

5. Gordon, C. J.; Workman, R. A.; Highfill, J. Thermoregulation in mice following acute administration of lead acetate. Neurotoxicol. Teratol. 9:193-196; 1987.

6. Graf, R.; Krishna, S.; Heller, H. C. Regulated nocturnal hypothermia induced in pigeons by food deprivation. Am. J. Physiol. 256:R733R738; 1989.

7. Hohtola, E.; Hissa, R.; Pyörnilä, A.; Rintamäki, H.; Saarela, S. Nocturnal hypothermia in fasting japanese quail: The effect of ambient temperature. Physiol. Behav. 49:563-567; 1991.

8. Husseini, R. H.; Sweet, C.; Collie, M. H.; Smith, H. Elevation of nasal viral levels by suppression of fever in ferrets infected with influenza viruses of differing virulence. J. Infect. Dis. 145:520-524; 1982.

9. Kluger, M. J. Fever: Its biology, evolution, and function. Princeton, NJ: Princeton University Press; 1979.

10. Kluger, M. J. Fever: Role of pyrogens and cryogens. Physiol. Rev. $71: 93-127 ; 1991$
11. Kluger, M. J.; Conn, C. A.; McClellan, J. L.; Maassab, H.; Smitka, C.; Majde, J. TNF $\alpha$ levels, physiological responses and behaviora changes associated with influenza viral pneumonitis. Cytokine 3 : $510 ; 1991$.

12. Lagerspetz, K. Y. H.; Väätäinen, T. Bacterial endotoxin and infection cause behavioural hypothermia in infant mice. Comp. Biochem. Physiol. [A] 88A:519-521; 1987.

13. Long, N. C.; Vander, A. J.; Kunkel, S. L.; Kluger, M. J. Antiserum against tumor necrosis factor increases stress hyperthermia in rats. Am. J. Physiol. 258:R591-R592; 1990.

14. Murphy, M. T.; Richards, D. B.; Lipton, J. M. Antipyretic potency of centrally administered alpha-melanocyte stimulating hormone Science 221:192-193; 1983

15. Naylor, A. M.; Gubitz, G. J.; Dinarello, C. A.; Veale, W. L. Vasopressin and fever: Evidence supporting the existence of an endogenous antipyretic system in the brain. Can. J. Physiol. Pharmacol. 65:1333-1338; 1987.

16. Scales, W. E.; Kluger, M. J. Effect of antipyretic drugs on circadian rhythm in body temperature of rats. Am. J. Physiol. 253:R306R313; 1987.

17. Watanabe, C.; Suzuki, T. Sodium selenite-induced hypothermia in mice: Indirect evidence for a neural effect. Toxicol. Appl. Pharmacol. 86:372-379; 1986 .

18. Webb, G. P.; Jagot, S. A.; Jakobson, M. E. Fasting-induced torpor in Mus musculus and its implications in the use of murine models for human obesity studies. Comp. Biochem. Physiol. [A] 72A:211$219 ; 1982$. 